\title{
Attitudes and Behaviors of Anesthesia Workers in Turkey Towards Drug Labeling: A Questionnaire Study
}

\section{Türkiye'de Anestezi Çalışanlarının İlaç Etiketleme ile IIlgili Tutumları ve Davranışları: Anket Çalışması}

(D) Gamze Küçükosman, (D) Bengü Gülhan Aydın, (D) Hilal Ayoğlu

Zonguldak Bülent Ecevit University Faculty of Medicine, Department of Anesthesiology and Reanimation, Zonguldak, Turkey

\begin{abstract}
Introduction: Standard drug syringe labels can reduce drug errors. In this study, it was aimed to report the attitudes of anesthesia workers (AW) towards labeling, to emphasize the importance of drug labeling in drug errors and to contribute to safe anesthesia practices by raising awareness about standardization.

Methods: The study was initiated after obtaining permission from the Zonguldak Bülent Ecevit University Clinical Research Ethics Committee. A confidential, self-reporting questionnaire was sent to each member of Turkish Anesthesiology and Reanimation Society and to technicians whose e-mail addresses were known.

Results: A total of 189 people participated. Of all participants, $49.2 \%$ were aware of standard syringe label (SSL). While $67.3 \%$ of these participants stated that they used color-coded selfadhesive labels, $47 \%$ stated that they did not know which standards these labels met. AWs suggested that color-coded selfadhesive labels (92.9\%), SSL for vials (97.3\%) and pre-prepared syringes (87.8\%) were effective in reducing drug administration errors (DAE). Of all participants, $89.9 \%$ stated that they did not know DAE and $84.7 \%$ stated that they read the label each time before administration. AWs stated that DAE could be prevented through standard labeling procedures (47\%), attention (23\%), education (21\%) and producing the vials in different sizes and colors (9\%).
\end{abstract}

Conclusion: AWs stated that developing and standardizing the vial labels, scheduling trainings, paying care and attention were important in prevention of labeling-related errors.

Keywords: Anesthesia workers, labeling, drug error, standardization öz

Amaç: Standart ilaç enjektör etiketleri ilaç hatalarını azaltabilir. Çalıșmamızda, ülkemizde anestezi çalıșanının (AÇ) ilaç etiketleme konusundaki tutumlarını, ilaç hatalarında etiketlemenin önemini vurgulamak ve standardizasyon bilincinin artmasına yönelik bir farkındalık yaratarak güvenli anestezi uygulamalarına katkı sağlanması amaçlanmıştır.

Yöntemler: Bu çalışma Zonguldak Bülent Ecevit Üniversitesi Klinik Araştırma Etik Kurulu'ndan izin alındıktan sonra tamamlandı. Türk Anesteziyoloji ve Reanimasyon Derneği'nin her üyesine ve posta adresleri bilinen teknisyenlere gizli, kendi kendini raporlama anketi gönderildi.

Bulgular: Toplam 189 kişi katıldı. Katılımcıların \%49,2'si standart enjektör etiketinin (SEE) farkındaydı. Bu katılımcıların $\% 67,3$ 'ü renk kodlu kendinden yapıșkanlı etiket kullandıklarını belirtirken, \%47'si bu etiketlerin hangi standartları karşıladığını bilmediklerini belirtmiştir. AÇ'ler ilaç uygulama hatalarını (IUH) azaltmak için; renk kodlu kendinden yapıșkanlı etiketlerin \%92,9, flakonların \%97,3 ve önceden hazırlanmış SSE'nin \%87,8 oranında etkili olacağını belirtti. Katılımcıların \%89,9'u IUH bildirmediğini, \%84,7'si, uygulama öncesi her defasında etiketi okuduğunu belirtti. AÇ'ler, IUH'yi önlemede SEE'nin (\%47), dikkat (\%23), eğitim (\%21) ve flakon-ampullerin farklı renk ve boyutlarda yapılması (\%9) gerektiğini belirtmişlerdir.

Sonuç: AÇ'ler, etiketleme ile ilgili hataların önlenmesi için; flakon etiketlerinin geliştirilmesinin ve standartlaştırılmasının, eğitimlerin planlanmasının, özen ve dikkatin önemini belirtmiștir

Anahtar Kelimeler: Anestezi çalıșanları, etiketleme, ilaç hatası, standardizasyon 


\section{Introduction}

Errors in drug selection and drug use are among the common adverse events in hospitals (1,2). The European Board of Anesthesiology and the European Society of Anesthesiology have stated that drug errors reduce patient safety, but that they can be prevented $(3,4)$. Most anesthesia workers (AW), who are responsible for completing all steps of drug administration, encounter drug errors in the complex and rapidly changing environment of the operating theater $(1,5)$. Each drug should be used at the right time, in the right dose and right order during the perioperative period. It is very easy to confuse the drugs. Color labels used for specific drugs reduce drug administration errors (DAE) and the standard syringe label (SSL) improves patient safety $(6,7)$. Most anesthesiologists suggest that the color of the label is an important factor for identifying a drug $(8,9)$.

The use of handwritten labels is a problem because it is easy to make mistakes either in writing or reading them. Therefore, the current drug syringe label situation has been documented as one of the primary causes of error. The International Organization for Standardization (ISO) and anesthesiology societies have guidelines focused on the development of prepared syringe labels for dosage, volume, dilution and color coding, and recommend standardization of syringe labeling $(10,11)$.

In our study, it was aimed to report the attitudes of AW (resident, specialist, lecturer, technician) towards labeling, to emphasize the importance of drug labeling in drug errors and to contribute to safe anesthesia practices by raising awareness about standardization.

\section{Methods}

This cross-sectional study was conducted between September 2016 and January 2017 with the permission of the Zonguldak Bülent Ecevit University Local Ethics Committee (decision no: 2016/10, date: 24.08.2016). Informed consent wasn't obtained because it was a survey study.

Data Collection Methods: AW in our country were contacted through the Turkish Anesthesiology and Reanimation Society (TARD), which have approximately 4000 members. The questionnaire form was created by reviewing the studies in the literature (Appendix). The questionnaire was sent with a text providing information about the subject. The data were obtained from the participants through a web-based questionnaire data form. The questionnaire was sent twice in 4-week intervals to each member of TARD and to technicians whose email addresses were known, and those who had participated previously were reminded not to participate again. The identities of the participants were kept confidential.

Questionnaire Form: The questionnaire consisted of four sections. The first section contained data on the demographic characteristics, duties, institutions and working years of the workers. The second section inquired about the experiences of drug errors, potential causes, and one or more factors for each event. The clinical outcomes of drug errors were reported. The third section included the ideas of AW on label and package characteristics, SSL awareness, the rate of colorcoded self-adhesive label use, and data on standardization of labels. The last section inquired about the rate of notifying drug errors and informing the patients about the event, the reasons for not notifying errors, whether AW were punished for the errors or not, whether they notified the errors to a national reporting program, and whether or not they asked the protocol from TARD for labeling and recommendations for prevention of drug errors. Except for the first section, multiple-choice questions in the other sections can be marked with multiple choices.

\section{Statistical Analysis}

Frequency (\%) of the answers of the volunteering participants was determined.

\section{Results}

A total of 189 questionnaires were evaluated. Demographic characteristics of the participants are presented in Table 1. A total of 325 DAEs were described and are shown in Table 2. Fifty-two point nine percent $(n=100)$ of the participants stated that they administered the incorrect drug during anesthesia induction at least once. Table 2 also displays the frequency of DAE observation. Results of DAE are explained in Table 3. When participants were asked to state the importance of some of the features they used to identify the syringe or the label, the label

\begin{tabular}{|c|c|c|}
\hline & & n (\%) \\
\hline \multirow{2}{*}{ Gender } & Female & $108(57.1)$ \\
\hline & Male & $81(42.9)$ \\
\hline \multirow{4}{*}{ Duty } & Anesthesia technician & $63(33.4)$ \\
\hline & Anesthesia specialist & $60(31.7)$ \\
\hline & Lecturer & $38(20.1)$ \\
\hline & Anesthesia resident & $28(14.8)$ \\
\hline \multirow{4}{*}{ Institution } & State hospital & $72(38.1)$ \\
\hline & University hospital & $64(33.9)$ \\
\hline & Training and Research Hospital & $34(18.0)$ \\
\hline & Private hospital & $19(10.0)$ \\
\hline \multirow{5}{*}{ Working years } & $<5$ years & $51(27.0)$ \\
\hline & $6-10$ years & $41(21.7)$ \\
\hline & $11-15$ years & 39 (20.6) \\
\hline & $16-20$ years & $26(13.8)$ \\
\hline & $>21$ years & $32(17.4)$ \\
\hline
\end{tabular}

Table 2. Frequency of observation of Drug Administration Errors $(\mathrm{n}=325)$

\begin{tabular}{|l|l|}
\hline Causes & n (\%) \\
\hline Injection of the drug in the incorrect dose & $53(16.3)$ \\
\hline Using the incorrect syringe & $45(13.8)$ \\
\hline Not reading the label & $42(12.9)$ \\
\hline Incorrect definition of the vial & $40(12.3)$ \\
\hline Incorrect labeling of the syringe & $36(11.0)$ \\
\hline Filling the syringe with incorrect drug & $35(10.7)$ \\
\hline Incorrect injection site & $25(25.0)$ \\
\hline Others & $49(15.0)$ \\
\hline
\end{tabular}

*Percentages do not sum to $100 \%$ because responders often reported multiple factors 
Table 3. Results of medication errors $(n=127)$

\begin{tabular}{l|l|}
\hline Effect of drug errors on outcomes & n (\%) \\
\hline $\begin{array}{l}\text { No clinical importance } \\
\begin{array}{l}\text { Minor morbidity (requiring immediate intervention for } \\
\text { prevention of permanent damage) }\end{array}\end{array}$ & $69(54.3)$ \\
\hline $\begin{array}{l}\text { Major morbidity (i.e. cardiac arrest, stroke or permanent } \\
\text { damage) }\end{array}$ & $48(37.7)$ \\
\hline Death (may lead or contribute to death) & $4(3.1)$ \\
\hline Others & $2(1.5)$ \\
\hline *Percentages do not sum to 100\% because responders often reported multiple factor
\end{tabular}

Table 4. Reasons for not reporting drug errors $(n=114)$

\begin{tabular}{|l|l|}
\hline Reasons & $\mathbf{n}(\%)$ \\
\hline The error was insignificant & $76(66.6)$ \\
\hline Not correctly knowing to where or whom to report & $19(16.6)$ \\
\hline Medico-legal concerns & $12(10.5)$ \\
\hline Concerns about the opinions of the colleagues & $5(4.38)$ \\
\hline Others & $2(1.75)$ \\
\hline
\end{tabular}

*Percentages do not sum to $100 \%$ because responders often reported multiple factors

color of the vial and the color of the vial were found to be "extremely important" at rates of $42.3 \%$ and $32.8 \%$, and the font size for prepared syringes was found to be "extremely important" at a rate of $44.4 \%$. Of the participants, $49.2 \%(n=93)$ were aware of SSL. While $66.7 \%$ of these participants stated that they used color-coded self-adhesive labels, $46.2 \%$ stated that they did not know which standards these labels met. Color-coded self-adhesive labels (92.9\%), standardized labeling system for vials (97.3\%) and the prepared syringes (87.8\%) were suggested by AW to be effective in reducing DAE. Of the participants, $89.9 \%(n=170)$ stated that they did not know DAE. Of the participants who notified DAE, $56.2 \%(n=16)$ stated that they reported the error to the chief of the clinic, but they did not report it to the official website of an institution, and three participants were found not to respond to this question. The reasons for not reporting DAE are presented in Table 4. The errors were not reported to the patients at a rate of $94.7 \%(n=179)$, and the rate of being not punished was $99.4 \%(n=182)$. Of the responders, $90.5 \%$ $(n=171)$ stated that they would notify the DAE if there were a single notification center and $95.8 \%$ stated that they wanted TARD to develop a protocol for labeling. AW $(n=100)$ stated that DAE could be prevented through standard labeling procedures (47\%), attention and care (23\%), training (21\%) and producing the vials in different sizes and colors (9\%).

\section{Discussion}

Our study revealed that most AW had at least one or more DAE experience, and that $54.3 \%$ of the errors were clinically insignificant. Most of the participants stated that color was the most important feature in the identification of drugs. We determined the rate of SSL awareness as $49.2 \%$ and the use of color-coded self-adhesive labels as $66.7 \%$; however, $46.2 \%$ of the participants did not know the standards required for the labels.

AW can make mistakes with loss of concentration despite problem solving, decision-making and application skills. DAEs may arise at any stage of the therapeutic procedure, and its incidence has been reported to be between $1-10 \%$, and this rate has been reported not to significantly change over a period of more than 15 years $(8,12-18)$. In two questionnaire studies, the rate of observation of one or more DAEs by AW was $\% 61.7$ and $\% 91.8(8,19)$. We determined that $52.9 \%$ of the participants experienced at least one DAE during anesthesia applications. We consider that AW may be reluctant to report all errors, and that the number of the reported errors is small given the large number of drugs used in anesthesia. Prospective studies are required to determine the prevalence of DAE, and our findings may lead to awareness of AW.

There are many reasons for DAEs in anesthesia applications. The most common causes of perioperative DAE include injection of the incorrect drug, administration of an excessive dose, incorrect route of administration and negligence. Inadequate follow-up of treatment or side effects, inadequate standardization of labels and protocols, carelessness, excessive workload, inappropriate working hours, poor communication, impetuousness, fatigue, medical and paramedical staff-related problems were also reported to contribute to DAE $(4,8,14,17-24)$. In addition, incorrect or missing drug labels, interchange of syringe labels and vials, unlabeled syringes, and failure to estimate the dose of the drug were also reported $(5,7,8,12,22)$. There are studies reporting that errors arise from interchange of the syringe (44.4\%-70.4\%) and incorrect definition of the label $(46.8 \%)(5,8,18,22)$. In our study, consistent with the literature, we found that errors were caused by many reasons such as incorrect drug and dose.

There are various measures for the prevention of DAEs in anesthesia as they are preventable and may be potentially fatal $(24,25)$. Regarding the recommendations for preventing DAEs, Russel W. (26) recommended different color codes for the syringes according to the drug types. The Japanese Society of Anesthesiology reported that outcomes of the series of preventive measures in preventing DAE were not satisfactory despite the current measures; and that the current syringe labels are among the main causes of DAE (27). The recommendations also include the use of international color codes for labeling and color syringes, and production of different looking drugs by drug companies $(17,22,28)$.

Considering the safety, designing labels is a step toward developing a safer system. Canada developed the first standardization for labeling vials and prepared syringes (14). Many countries use a standard color code for anesthetic drug syringes. Many studies have reported that the rate of SSL use is between $19 \%$ and $96 \%$, while some authors report that they have developed their standards, and some others report that they use the color codes of ISO standards $(3,8,9,17,28-30)$. Orser et al. (8) reported the rate of awareness of anesthetists regarding self-adhesive color-coded labels as $86.5 \%$ in their questionnaire study, and $84 \%$ of the participants in this study stated that drug label standards would reduce the incidence of DAE. In our study, consistent with the literature, we determined that the standard labeling procedure was an important factor in the prevention of DAE. We also determined that the rate of awareness and use of SSL in our study was lower than European data. No mandatory regulations are available for labeling standardization in our country, and our study revealed that AW supported labeling standards. We also determined that AW did not know the standards from which the color-coded labels were prepared and they suggested that TARD should 
participate in the protocol selection. We believe that AW should demand from hospital pharmacists and Ministry of Health that drug labels be prepared in accordance with the international standards.

It has been reported that specific protocols should be developed for prevention of DAE, trainings should be scheduled, routines for equipment care and control should be improved, and that more manpower and communication should be provided (22). We think that DAE may be reduced with similar measures.

Some DAE may lead to severe morbidity and even mortality, although most of them are not significant $(12,21)$. The reason for minor morbidities caused by DAE in anesthesia include early recognition of the error, rapid physiological changes caused by drugs and special follow-up methods in critical events. There are also studies reporting mortality $(5,8,12,14,21,22)$. We detected that the adverse events in our study were consistent with the literature and most of them resulted in minor morbidities, with only four deaths with unknown origin.

Orser et al. (8) reported that $60.1 \%$ of DAEs in anesthesia applications were not reported due to being considered as insignificant. The participants also reported that they did not know where to and whom to report the errors. In the same study, almost half of the participants reported that they would report the errors to a national notifying program. It is also known that DAEs are not reported individually or by the department $(2,17)$. In our questionnaire, we observed that $89.9 \%$ of the errors were not reported and, if reported, they were mostly reported to the chief of the department. A Safety Notifying System (www.kalite.saglik.gov.tr) is available in our country; however, most AW are unaware of this website and we consider that critical errors should be reported in accordance with the relevant rules.

One limitation of our study is that our study was a web-based questionnaire study and the number of responders was less than similar studies in the literature. Therefore, the results may not reflect the attitudes of all AW. Besides, the prevalence cannot be determined, as the details of the errors experienced years ago could have been forgotten.

The results of the present study may in general present the preliminary data for the development of quality standards in our country. We observed that most AW participating in the study did not use SSL, and that more than half experienced at least one DAE, and that these were caused by mislabeling.

\section{Conclusion}

In our study, AW stated that developing and standardizing the vial labels, scheduling trainings, paying care and attention were important for the prevention of labeling-related errors. In addition, DAEs were not frequently reported. Anesthetists and managers should be aware of this problem. Notification mechanisms should be utilized for the prevention of potential events and future events, and determination of the measures. Prospective randomized studies are required for investigating strategies to reduce DAEs. The use of error notification systems would develop a safer patient culture.

Ethics Committee Approval: This cross-sectional study was conducted between September 2016 and January 2017 with the permission of the
Zonguldak Bülent Ecevit University Local Ethics Committee (decision no: 2016/10, date: 24.08.2016).

Informed Consent: Informed consent wasn't obtained because it was a survey study.

Peer-review: Externally peer-reviewed.

Author Contributions: Concept - H.A.; Design - G.K., H.A.; Data Collection and/or Processing - G.K., B.G.A.; Analysis and/or Interpretation - G.K. B.G.A.; Literature Search - G.K.; Writing Manuscript - G.K.; Critical Review - B.G.A.

Conflict of Interest: The authors have no conflict of interest to declare.

Financial Disclosure: The authors declared that this study has received no financial support.

\section{Attitude and Behavior of Anesthesia Workers about Labelling in Anesthetic Drug Administration}

Dear colleagues,

The following questions were prepared with the aim of determining attitudes and behaviors about labeling in anesthetic drug administration. Answering the questions is optional. You will not be prompted to enter your first name or last name on the forms. Confidentiality will be ensured by researchers. After reading the statements, please mark the appropriate choice. The survey should take approximately 10 minutes. If you have already answered this survey, please do not complete it again. Thank you in advance for answering our survey.

(Asst. Prof. Dr. Gamze Küçükosman, Bülent Ecevit University, Dept. of Anesthesiology and Reanimation, Zonguldak)

\section{Note: *Mandatory questions}

\section{SECTION 1}

1. Your job*:

1. Anesthesia assistant

2. Anesthesia specialist

3. Teaching staff

4. Anesthesia technician (vocational school of higher education)

5. Anesthesia technician (vocational high school)

\section{Your gender*:}

1. Female

2. Male

\section{How long have you been in the anesthesia profession? (Including} your education)*

1. $0-5$ years

2. $6-10$ years

3. $11-15$ years

4. $16-20$ years 


\section{5. $21-25$ years \\ 6. $>25$ years}

4. Hospital of employment*:

1. State hospital

2. Training and Research hospital

3. Private hospital

4. University hospital

\section{SECTION 2}

5. Have you ever experienced giving the incorrect drug to any patient during anesthesia administration?*

1. Yes (go to the $6^{\text {th }}$ question)

2. No (go to the $9^{\text {th }}$ question)

6. Did any of the following factors affect this drug error? If your answer is yes, please state the error number, you may mark multiple choices.

1. Misidentification of ampoule or vial......

2. Mislabeling of syringe.

3. Incorrect injector used.

4. Illegibility of label

5. Incorrect drug in the syringe.

6. Incorrect administration site.

7. Incorrect dose of drug injected...........

8. Other (please give details)....

7. If you answered the $6^{\text {th }}$ question, please state any other reason or reasons that you think caused drug errors

8. What was the outcome of the event(s) related to drug administration error you were involved in? (You may mark multiple choices)

1. No clinical importance

2. Minor morbidity (requiring rapid intervention to prevent permanent injury)

3. Major morbidity (e.g., heart attack, paralysis or permanent injury)

4. Death (caused or contributed to death)

5. Other (please give details).

\section{SECTION 3}

9. What is the importance of labeling that helps in the identification of anesthetic drugs?*

(Mark one box in each row).

$\mathbf{0}=$ not important

$\mathbf{2}=$ moderately important

$\mathbf{1 = s l i g h t l y ~ i m p o r t a n t}$

$\mathbf{3}=$ very important

\begin{tabular}{|c|c|c|c|c|c|c|}
\hline \multicolumn{3}{|l|}{ Ampoules } & 0 & 1 & 2 & 3 \\
\hline \multicolumn{3}{|c|}{ Ampoule color } & - & - & - & - \\
\hline \multicolumn{3}{|l|}{ Label colors } & - & - & - & - \\
\hline \multicolumn{3}{|l|}{ Font size } & - & - & - & - \\
\hline \multicolumn{3}{|l|}{ Font type } & - & - & - & - \\
\hline \multicolumn{3}{|l|}{ Ampoule size } & - & - & - & - \\
\hline \multicolumn{3}{|c|}{ Color band at ampoule break point } & - & - & - & - \\
\hline Vial & 0 & & 1 & 2 & 3 & \\
\hline Vial color & - & & - & - & - & \\
\hline Vial lid color & - & & - & - & - & \\
\hline Font color & - & & - & - & - & \\
\hline Font size & - & & - & - & - & \\
\hline Font type & - & & - & - & - & \\
\hline Vial size & - & & - & - & - & \\
\hline Vial shape & - & & - & - & - & \\
\hline \multicolumn{2}{|c|}{ Previously filled syringes } & 0 & 1 & 2 & \multicolumn{2}{|c|}{3} \\
\hline \multicolumn{2}{|l|}{ Font color } & - & - & - & \multicolumn{2}{|l|}{-} \\
\hline \multicolumn{2}{|l|}{ Font size } & - & - & - & \multicolumn{2}{|l|}{-} \\
\hline \multicolumn{2}{|l|}{ Font type } & - & - & - & \multicolumn{2}{|l|}{ - } \\
\hline Syringe size & & - & - & - & - & \\
\hline
\end{tabular}

10. Are you aware of the usefulness of standardized color-coded labels for anesthetic drug syringes?*

1. Yes (go to the $11^{\text {th }}$ question)

2. No (go to the $13^{\text {th }}$ question)

11. If yes, do you use these color-coded self-adhesive labels?

1. Yes (go to the $12^{\text {th }}$ question)

2. No (go to the $13^{\text {th }}$ question)

12. If yes, what standards do these color-coded self-adhesive labels meet?

1. Canadian Anesthesiologists' Society

2. FDA (Food and Drug Administration)

3. ASA American Society of Anesthesiologists

4. Ministry of Health Pharmacy and Pharmacology Unit

5. I don't know

6. Other (please give details)

13. Please state the degree of agreement/disagreement with the following statements*

(Mark one box for each row)

$\mathbf{0}=$ Definitely disagree

1=Partly agree

$\mathbf{2}=$ Mostly agree

$\mathbf{3}=$ Definitely agree 


\begin{tabular}{|l|l|l|l|l|}
\hline & $\mathbf{0}$ & $\mathbf{1}$ & $\mathbf{2}$ & $\mathbf{3}$ \\
\hline $\begin{array}{l}\text { 1. Color-coded self-adhesive labels will } \\
\text { reduce the incidence of drug errors in } \\
\text { anesthesia }\end{array}$ & - & - & - & - \\
\hline $\begin{array}{l}\text { 2. Standardized systems for medication } \\
\text { ampoule and vial labeling will reduce } \\
\text { the incidence of drug errors }\end{array}$ & - & - & - & - \\
\hline $\begin{array}{l}\text { 3. Previously prepared injectors for } \\
\text { anesthesia will reduce drug errors }\end{array}$ & - & - & - & - \\
\hline $\begin{array}{l}\text { 4. If all anesthetic medications have } \\
\text { the same appearance the incidence of } \\
\text { drug errors will reduce }\end{array}$ & - & - & - & - \\
\hline
\end{tabular}

\section{SECTION 4}

\section{Have you reported any drug error?*}

1. Yes

2. No

15. If yes, to whom and where did you report the drug error?

16. If you have not reported an error (errors), why?* (You may mark multiple choices)

1. No errors

2. The error was insignificant

3. Concerns about my colleagues' opinions

4. Uncertainty about whom or where to report

5. Concerns related to medico-legal risks

6. Other (please give details)

\section{Did you tell the patient about the drug errors?}

1. Yes

2. No

18. Were you punished due to drug administration error?

1. Yes (go to the $19^{\text {th }}$ question)

2. No (go to the $20^{\text {th }}$ question)

19. If yes, please state the type of punishment and who gave it.

20. If there was a single reporting center for anesthetic medication errors, would you report error(s) to this unit?*

1. Yes

2. No

21. Would you like our association to issue protocols to prevent drug errors?*

1. Yes

2. No

22. What precautions do you think should be taken to prevent drug errors in relation to labeling?*

Comment:

\section{References}

1. Merry AF, Peck DJ. Anaesthetists, errors in drug administration and the law. $N$ Z Med J 1995; 108: 185-7.

2. Bates DW, Cullen DJ, Laird N, Petersen LA, Small SD, Servi D, et al. Incidence of adverse drug events and potential adverse drug events. Implications for prevention. ADE Prevention Study Group. JAMA 1995; 274: 29-34.

3. Christie IW, Hill MR. Standardized colour coding for syringe drug labels: a national survey. Anaesthesia 2002; 57: 793-8.

4. Mellin-Olsen J, Staender S, Whitaker DK, Smith AF. The Helsinki declaration on patient safety in anaesthesiology. Eur J Anaesthesiol 2010; 27: 592-7.

5. Fasting S, Gisvold SE. Adverse drug errors in anesthesia, and the impact of coloured syringe labels. Can J Anesth 2000; 47: 1060-7.

6. Merry AF, Webster CS, Connell H. A new infusion syringe label system designed to reduce task complexity during drug preparation. Anaesthesia 2007; 62: 486-91.

7. Webster CS, Merry AF. British syringe label 'standards' are an accident waiting to happen. Anaesthesia 2000; 55: 618.

8. Orser BA, Chen RJ, Yee DA. Medication errors in anesthetic practice: a survey of 687 practitioners. Can J Anaesth 2001; 48: 139-46.

9. Radhakrishna S. Syringe labels in anaesthetic induction rooms. Anaesthesia 1999; 54: 963-8.

10. International Organization for Standardization. Anaesthetic and respiratory equipment-User-applied labels for syringes containing drugs used during anaesthesia-Colours, design and performance. 1st ed. Geneva: ISO, 2008. ISO 26825:2008(E)

11. American Society of Anesthesiologists. Statement on creating labels of pharmaceuticals for use in anesthesiology, 2015. http://www.asahq.org/ / media/Sites/ASAHQ/Files/Public/Resources/standardsguidelines/statementon-labeling-ofpharmaceuticals-for-use-in-anesthesiology.pdf. Accessed 20 Jan 2017.

12. Webster CS, Merry AF, Larsson L, McGrath KA, Weller J. The frequency and nature of drug administration error during anaesthesia. Anaesth Intensive Care 2001; 29: 494-500.

13. Webster CS, Larsson L, Frampton CM, Weller J, McKenzie A, Cumin D, et al. Clinical assessment of a new anaesthetic drug administration system: a prospective, controlled, longitudinal incident monitoring study. Anaesthesia 2010; 65: 490-9.

14. Zhang Y, Dong YJ, Webster CS, Ding XD, Liu XY, Chen WM, et al. The frequency and nature of drug administration error during anaesthesia in a Chinese hospital. Acta Anaesthesiol Scand 2013; 57: 158-64.

15. Merry AF, Webster CS, Hannam J, Mitchell SJ, Henderson R, Reid P, et al. Multimodal system designed to reduce errors in recording and administration of drugs in anaesthesia: prospective randomised clinical evaluation. BM] 2011; 22; 343:d5543.

16. Nanji KC, Patel A, Shaikh S, Seger DL, Bates DW. Evaluation of Perioperative Medication Errors and Adverse Drug Events. Anesthesiology 2016; 124: 25-34.

17. Gordon PC, Llewellyn RL, James MF. Drug administration errors by South African anaesthetists-a survey. S Afr Med J 2006; 96: 630-2.

18. Sakaguchi Y, Tokuda K, Yamaguchi K, Irita K. Incidence of anesthesia-related medication errors over a 15-year period in a university hospital. Fukuoka Igaku Zasshi 2008; 99: 58-66.

19. Erdmann TR, Garcia JHS, Loureiro M, Monteiro MP, Brunharo GM. Profile of drug administration errors in anesthesia among anesthesiologists from Santa Catarina. Rev Braz Anesthesiol 2016; 66: 105-10.

20. Dhawan I, Tewari A, Sehgal S, Sinha AC. Medication errors in anesthesia: unacceptable or unavoidable? Braz J Anesthesiol 2017; 67: 184-92. 
21. Currie M, Mackay P, Morgan C, Runciman WB, Russell WJ, Sellen A, et al. The Australian Incident Monitoring Study. The "wrong drug" problem in anaesthesia: an analysis of 2000 incident reports. Anaesth Intensive Care 1993; 21: 596-601.

22. Abeysekera A, Bergman IJ, Kluger MT, Short TG. Drug error in anaesthetic practice: a review of 896 reports from the Australian Incident Monitoring Study database. Anaesthesia 2005; 60: 220-7.

23. Cooper L, Nossaman B. Medication errors in anesthesia: a review. Int Anesthesiol Clin 2013; 51: 1-12.

24. Orser BA, Hyland S, David U, Sheppard I, Wilson CR. Review article: improving drug safety for patients undergoing anesthesia and surgery. Can J Anesth 2013; 60: 127-35.

25. Jensen LS, Merry AF, Webster CS, Weller J, Larsson L. Evidence-based strategies for preventing drug administration errors during anaesthesia. Anaesthesia 2004; 59: 493-504.
26. Russell W. Getting into the red: a strategic step for safety. Qual Saf Health Care 2002; 11: 107

27. Safety Committee of Japanese Society of Anesthesiologists. Preventing medication errors in the perioperative setting: recommendations on drug syringe labels. J Anesth 2017; 31: 304-6.

28. Wickboldt N, Balzer F, Goncerut J, Michel PA, Staender S, Kinnaer R, et al. A survey of standardised drug syringe label use in European anaesthesiology departments. Eur J Anaesthesiol 2012; 29: 446-51.

29. DCAN/CSA-Z264.2-99 (R2009) Labelling of drug ampoules, vials, and prefilled syringes. Mississauga, (ON): CSA Group; 1999 [reaf- firmed 2009].

30. Levrat Q, Troitzky A, Levrat V, Debaene B. Syringe drug labels: a French national survey. Ann Fr Anesth Reanim 2008; 27: 384-9. 